\title{
Education, Status and Income - An Established Triangle Disrupted by New Qualifications?
}

\author{
Silvia Annen, Michael Tiemann \\ Federal Institute for Vocational Education and Training \\ Germany
}

\begin{abstract}
This article examines the relations between employees' educational attainment and their income as well as their social status, considering the individuals' social background. The data derive from the German BIBB/BAuA Employment Survey 2012. Social status is analyzed for the individuals' first job and their current job using the International SocioEconomic Index of Occupational Status (ISEI). The results show that academic and further vocational qualifications have a positive effect on employees' income compared to initial vocational qualifications. Especially academic qualifications are positively related to employees' social status, while over time also (initial and further) vocational qualifications have a positive effect. The individuals' social background is also positively related to their educational attainment - mostly for the group of academically qualified employees.
\end{abstract}

\section{Introduction}

The presented results derive from a project set up to identify typical educational pathways and careers in commercial occupations in selected industry sectors (commerce, banking, logistics and tourism). The objective is to identify possibly competitive situations between occupational (VET qualifications) and academic qualifications (bachelor's and master's degrees). It also evaluates the utilization of qualifications and skills for the respective educational programs with regard to occupational and social status as well as income. The research concept combines qualitative and quantitative methods.

From a sociological perspective these educational pathways and careers are ways leading to positions with specific social status. But when we assume that vocational and academic pathways lead to the same position within a company, can we also safely assume that the status of these positions will be the same? The following results mark a first step in answering these questions: Here, we want to assess whether there is a difference in the status of positions achieved by persons with different educational attainments. Especially regarding the outcomes of BA qualifications this has, to our knowledge, not been looked into yet.

In Germany the discussion about the relationship between vocational certificates and higher education certificates has been triggered by the higher education structural reform in 1999 (Bologna process) and the implementation of the German Qualifications Framework (GQF) in 2013. Figure 1 shows the relevant structure of the GQF exemplary for the commerce sector.

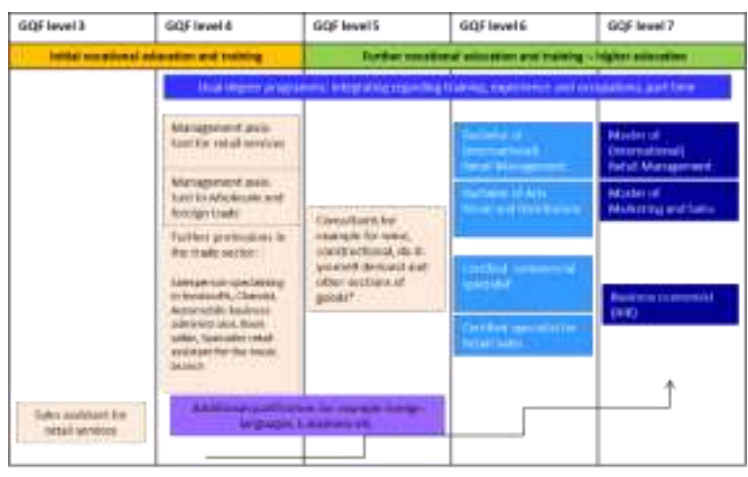

Figure 1. GQF levels of selected training Programmes

There is the assumption of a competition between vocational and higher education qualifications on the labour market and substitution tendencies favouring persons with higher education qualifications. Furthermore it is assumed that the competition in the employment system is high in particular when there are strong similarities regarding the demands on the activities to be performed by academically and vocationally qualified employees. At the same time complementary qualification profiles exist where companies tend to differentiate into different tasks and areas of work accordingly.

Former surveys show that there are differences between industry sectors. Company-internal personnel structure and training activity of the 
companies influence the competitive relationships as well.

The intended practical impact of the research results is to gain insights about the usability of selected qualifications on the job market in order to develop ideas for the future structure of vocational education and training programs.

\section{Methodological design and data}

The research concept combines qualitative and quantitative methods. A document analysis of curricula of corresponding vocational and academic qualifications is conducted. The selection of these qualifications is based on the German Qualification Framework, focusing on level 6, where Bachelor degrees and equivalent vocational degrees are allocated. To find comparable occupational positions the national classification of occupations, which includes information on qualification requirements, is used. On the academic side bachelor degrees are in the focus of the project, while master degrees are also considered where appropriate. On the vocational route three GQF-levels for further trainings regulated by public law can be differentiated. The first level ("Fachberater") is linked to level 5. Master craftsmen and comparable vocational degrees ("Meister" and "Fachwirte") are linked to level 6, which is equivalent to bachelor degrees and for this reason in the focus of the project. The third group ("Betriebswirte") is linked to level 7, which is equivalent to master degrees.

Furthermore vacancies analyses with regard to respective company positions and activities are conducted. In a database of more than two million job advertisements from 2011 on we are able to depict the link between qualification and skill requirements. Even though there are not many positions open for candidates with a bachelor's degree we do have information on the link between the positions firms want to appoint successful candidates, their respective tasks and required skills. We can then compare this to positions, tasks and skills for vocationally qualified persons.

Case studies as well as a company survey are undertaken examining the recruitment strategies of enterprises in the commerce, banking, logistics and tourism sectors. Finally a follow-up survey to the 2018 employment survey is conducted to assess the usability of vocational and academic qualifications. These parts use quantitative and / or qualitative methods as appropriate and are linked to each other as results of one are used for the others.

The following results are based on an analysis of the educational attainment in relation to social status, social background and income using data from the German BIBB/BAuA Employment Survey 2012 [1], here labelled as "Employment Survey 2012". This is a representative computer-assisted telephone interview (CATI) survey of 20,036 persons in coreemployment. Being in core-employment means that one holds a paid job with a working time of at least 10 hours per week. The mean interview time was about 40 minutes. Respondents gave self-assessed information on different aspects of their working conditions, the tasks to be performed, fields of knowledge they have to be proficient in, different qualification and situational requirements and also their qualification paths with up to five completed programs. For more information see [2]. The data are weighted with a structural weight with the German Microcensus 2012 as the reference structure. Due to its large sample size the data allow for detailed analyses in large enough sub-populations as well as comparisons between different groups.

The groups of persons with different qualifications build on information about the highest occupational qualification a respondent in the Employment Survey has. Actually, one could have more than just one qualification (like with Mastercraftsmen, who have to have a VET qualification or like academic master graduates, who have to have a bachelor's degree beforehand. Only the highest qualification is considered (not the latest, this happened only when there were more than one qualification on the same level).

To answer the above research questions on educational attainment, social status and income we first look into the relative differences in income for employed persons with different qualifications.

For an assessment of income differences it would be best to look into data on life-time income, differentiated by qualifications. Since we do not have such data in this project, we utilise the approach of comparing differences in mean gross income. Gross income differentials are computed with the Employment Survey 2012 data, restricting the analyses to persons with their highest education being either academic or vocational training. For this analysis four levels are differentiated: academic qualification (including all academic education except for bachelors' degrees), bachelors' degrees, further education and initial vocational education and training (IVET).

The following formula is used to compare income gains due to an academic qualification compared to an average income in this training period for someone with a vocational training: $r_{i}=\left(\overline{Y_{l a}}-\overline{Y_{l v}}\right) /\left(d^{\prime}{ }_{i a} * \overline{Y_{l v}}\right)$, with $r_{i}:=$ return to investment in education in occupation $i ; \overline{Y_{l a}}:=$ average gross income in occupation $i$ for those with academic training; $\overline{Y_{l v}}:=$ average gross income in occupation $i$ for those with vocational training and $d_{i a}^{\prime}:=$ (estimated) average duration of academic training for occupation $i$. This approach allows us to assess the relative gains or losses of persons due to their respective qualifications. 
Second we search for differences in these qualification groups regarding social status. Social status is assessed using the ISEI, the "International Socio-Economic Index of Occupational Status" [22, 23]. The ISEI is actually linked to occupations and considers income, qualification and parental status. Since it is measured on a metric scale with a minimum of 11 and a maximum of 89 points occupations can have rather similar ISEI-scores. This opens up the possibility for similar ISEI-scores for different occupations and for persons with different qualification backgrounds. If we do find similar scores for persons in comparable positions but with different qualifications we could assume that their educational attainments did not influence their later position. If we do see persistent differences though, we would have to assume that educational attainment has an influence even though according to frameworks like the GQF people should be able to achieve similar outcomes.

\section{Theoretical reflections}

Generally Germany expects deep changes in the educational system and on the labour market due to the introduction of the three years lasting, vocationally qualifying bachelor, programmes. There are two central arguments for the substitution or even erosion of apprenticeships and firm-based trainings. First, due to changes in the recruitment patterns of firms, vocationally trained persons could be competing with academically trained bachelor graduates for the same positions. Second, students leaving school with a higher degree allowing them to go to a university could increasingly flow into bachelor programmes instead of taking up an apprenticeship.

Changing recruiting strategies of firms in favour of academically trained graduates would cut traditional vocational career paths and thus reduce the attractiveness of the German VET-system. Commercial and theory oriented occupations are expected to experience high competition between vocationally and academically (especially in bachelor programmes) trained graduates, unlike industrial and skilled manual occupations [27].

The new bachelor programmes have comparable duration to apprenticeships (leaving aside the possibility of shortening VET programmes for highperformance trainees), but promise higher prestige and higher wage classification and give access to a broader set of follow-up programmes [24, 25, 28].

Several surveys among companies have been conducted to learn more about the acceptance of, experiences with bachelor graduates and if already experienced the first steps of bachelor graduates " career paths. The results differ and show relatively high acceptance and positive employment prospects of bachelor graduates [29, 30]. But there is also dissatisfaction due to the fact that bachelor programmes are considered as being out of step with the actual practice [31].

Former research proves that the social background influences the occupational position over and above the educational attainment [4]. Furthermore in Germany the upward mobility to tertiary education is lower than the OECD average and the higher one's parents education, the more likely one is to achive earnings above average [6].

Different training types might lead to different competences, providing access to different occupations and different income opportunities. This idea has also lead to thesis as proposed by $[11,12]$ and [14] where persons with a medium-level qualification are per se seen as having worse chances on the labour market, as they would loose in employment and also wages, while persons with low and high qualifications would gain both in employment and wages. This broad idea of a polarization of the labour market. Whether this would also hold for more detailed qualification groups - or even levels, remains to be seen.

There are also research results stating that changes in the job market are met better by persons with an academic qualification [7, 8]. Specific training pathways remain closed to persons with lower qualifications [16] and paths to (and even within) academic and occupational training programmes are also dependent on the individuals' social background [6, 15]. However, the segmentation theory tells about the importance of duration of employment for arriving at higher positions $[17,18]$.

Focusing on the economics of education besides income further elements can affect educational decisions, like job security and career prospects, satisfaction with training and employment, and social status. Those four aspects are not always entirely discrete and may also be interdependent [3: 319f]. Furthermore several studies in social stratification research have shown that social background influences individuals' occupational position, and that this effect holds over and above educational attainment [4: $1 ; 5]$.

According to the PIAAC data $22 \%$ of $25-34$ yearold non-students have attained tertiary education although their parents have not. For example in Germany and the United States the share of such upward mobility to tertiary education is even lower than on OECD-average. An interesting fact regarding the monetary output of educational attainment is that when "parents' education is taken into account, adults with tertiary education are 23 percentage points more likely than those with upper secondary or post-secondary non-tertiary education as their highest level of education to be among the top 25 percent in monthly earnings, on average" [6: 78]. 
Both structural and individual aspects have to be distinguished when analyzing the monetary and social outcome of educational pathways. From a structural point of view, differences between individuals can arise in the form of wage differences. From an individual point of view, differences arise when training decisions lead to the development of different competences, which then provide access to different occupations. Following [7] and [8], differences derive primarily from different individual competences. In their reasoning the growing demands for qualifications in the job market are better met by individuals who have had an academic education, since such an education encourages building competences that make it easier to handle complex work requirements. Individuals with an academic education should therefore find their qualifications more usable in the job market.

This argumentation is not free of contradiction [9]. As the requirements for knowledge work are increasing, vocational experience and competence are gaining in relevance for problem-solving in occupational action scenarios [10]. Accordingly, vocational experience and qualifications with a high share of hands-on training should be attributed a high rank.

Based on a human capital approach and research in the context of Skill-Based Technological Change (SBTC) and Task-Based Technological Change (TBTC) $[11 ; 12 ; 13 ; 14]$, it can be assumed that, from a structural point of view, different qualifications lead to different income and employment opportunities.

Since the career paths for individuals with a vocational and individuals with an academic education differ in content, the question of social inequality should be considered as well. [15] document that the social background plays a major role in the transition within the educational system. Different career paths are only the second step and follow after an individual's educational pathway. [16] points out that specific training pathways - in fact, the ones that lead to attractive careers - remain closed to applicants with lower secondary schoolleaving certificates due to occupational closing and segmentation. The social inequality described by [15] can thus also originate here. This also shows that educational pathways are segmented in themselves and a kind of "filtering" takes place, where individuals only seldom move out of predescribed pathways. However, during a longer period of employment with the same company, individuals can enter into other segments of the job market in the company, as described in segmentation theory $[17 ; 18]$.

\section{Monetary and social attainment of employees depending on their education}

The discussion outlined above sets the background for this research project. The main question is that of competition versus complementarity of academic and vocational training. More specifically, we will look at a number of branches, occupations and occupational positions, where a high competition between academically and vocationally trained employees is to be expected. These sectors include finance, tourism and trade, among others. In some of them there are traditions of vocational qualification paths leading to higher occupational positions (e.g. in trade) and others where academic qualifications, sometimes combined with in-company trainings, already form the major pathway to higher positions (e.g. in finance) [32].

The employment survey's data give us a representative view on the outcomes of recruitment processes, since the respondents all are in employment. We can assess which educational career paths the employees took. For this the information on the qualification careers are used. They are ordered temporally and we can then see what qualification programs respondents went through over time. These are only programs they graduated from. For example, a person could start out with an apprenticeship and after that achieve a bachelor's degree or complete further training and achieve a master craftsman's certificate. Figure 2 shows the situation over all employees. Slightly more than two thirds $(67.8 \%)$ first complete a vocational education and training (VET) program. Nearly one out of ten persons starts by achieving another academic qualification besides a bachelor's degree $(9.4 \%)$. Of those who started with a VET certificate, $8.9 \%$ complete further training. Only 5.4 $\%$ acquire a bachelor's degree after initial VET.

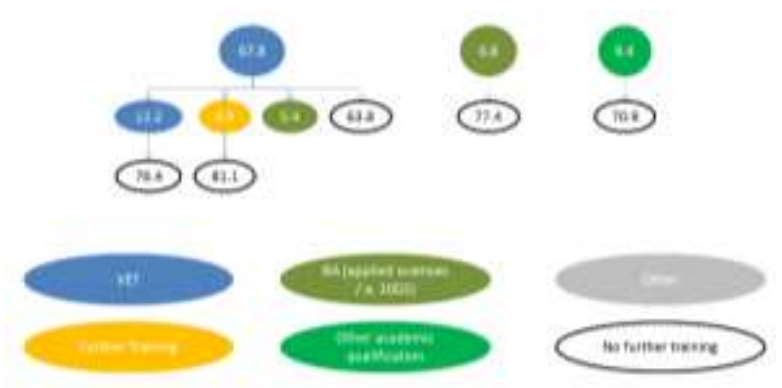

Source: BIBB/BAuA Employment Survey 2012, weighted, own calculations.

Figure 2. Career paths over all employed persons

The quality of employment is depicted by matching required and held qualifications. For required qualifications respondents' information on what level of qualification is needed to perform their current job is compared to their highest acquired 
qualification. Both are recoded into the same fourlevel scheme of "no vocational training" ("no qualification"), "vocational education and training" ("VET"), "further training" and "academic qualification" (here including bachelors' degrees). Weighted cross-tabulations show the shares of employed persons' highest achieved qualifications working on positions requiring specific qualifications. Table 1 shows the results over all persons in core-employment in Germany in 2012.

Overall we see that matching rates are quite high for persons without a qualification, with a VET qualification and highest for those with an academic qualification $(76.9 \%)$. Only on the level of further training we see a high share of persons working on positions requiring a lower qualification $(47.0 \%$ require VET training). Also, only few persons with further training $(8.4 \%)$ or academic training $(3.5 \%)$ work on positions requiring the other qualification. This is a rather strong hint for closed segments and low permeation between this segments of tertiary education.

Table 1. Qualification match of all employed persons

\begin{tabular}{|c|c|c|c|c|c|}
\hline \multirow{2}{*}{$\begin{array}{l}\text { Achieved } \\
\text { Qualificotion }\end{array}$} & \multicolumn{4}{|c|}{ Arquired qualification (raw pert)- } & \multirow{2}{*}{$\begin{array}{l}\text { Total (abs, in } \\
\text { Thousands) }\end{array}$} \\
\hline & No Qual & VIf & $\begin{array}{l}\text { Eurther } \\
\text { Training }\end{array}$ & $\begin{array}{l}\text { Acodemic } \\
\text { Ouvi: }\end{array}$ & \\
\hline No Qual. & 66.1 & 312 & 2.1 & 5.7 & $3,170,782$ \\
\hline VET & 19.4 & 72.6 & 4.4 & 3.6 & $20,954,177$ \\
\hline Further Training & 4.9 & 470 & 39.7 & 8.4 & $2,705,634$ \\
\hline Academic Qual & 5.28 & 14.3 & 35 & 76.9 & $8,515,586$ \\
\hline Total & 18.6 & 52.9 & 6.7 7 & 21.8 & $35,346,179$ \\
\hline
\end{tabular}

In Table 1 we see that nearly $73 \%$ of employees hold a VET qualification where one is required. In total only a small minority of jobs requires further training or an academic qualification (6.7 \% and 21.8 $\%$ respectively), with the high share of VET qualifications $(52.9 \%)$ corresponding to the picture drawn by the career paths and the relative importance of these qualification programmes in Germany.

To gain insights of the shares of matched employees in different sectors, which determine the quality of occupations, the qualification matching has to be calculated for these sectors. The results for the trade sector exemplary show that the shares of matched employees are quite high. $(66.1 \%$ for no qualification, $72.1 \%$ for VET, $31.9 \%$ for further training and $40.9 \%$ for academic qualification. In this sector VET training plays a major role in required qualifications with $61.3 \%$ overall. Overqualification for those with further training is relevant here as well with a share of $58.2 \%$ of employees with further training on positions requiring VET training.)
But we also see that the highly institutionalized link between education system and labor market with occupations forming a link between them favors VET trainings with employees having acquired certificates from regulated VET programs. As long as the share of positions requiring an academic qualification is not dramatically rising, competition here might not be a prominent problem. On the other hand such an increase might be driven by higher shares of persons with a bachelor's degree flowing into the labor market and firms reacting to this change in supply with an accordingly higher demand for academically trained persons.

The following paragraphs show results on income differences in relation to educational attainment derived from using the so-called "shortcut-method" [19] to denote the private return to investment in education [3: 314f]. Here we give a brief summary of the more detailed analyses reported in [20].

The results show that in Germany academic qualified employees on average achieve higher incomes than employees qualified in further educational programs (see Table 2). Only comparing bachelor graduates to persons who have completed further education (line two) instead of all academics, this positive effect turns negative (for a detailed analysis of different Occupational Main Fields see [21]). The results are even clearer when using IVET as a standard of comparison. Employees whose highest qualification derives from IVET achieve lower incomes than those with an academic as well as a further training qualification. It is noticeable that the income advantage of employees who hold a bachelor's degree (line four) is considerably smaller than that of further trained and academic qualified employees.

Overall the results show that academic education as well as further education lead to higher incomes, which means a positive return on investment in postsecondary education above IVET level. Furthermore within the group of academically qualified persons employees who hold a bachelor's degree take the lowest monetary advantage out of their qualification.

Besides the monetary aspect theoretical reflections suggest that educational pathways and qualifications are related to individuals' social status. To evaluate this different levels of education are analyzed in comparison to the social status of employees and their social background. Hereby the following levels of education are differentiated: no formal qualification, initial vocational qualification, further vocational qualification, bachelor degrees' qualification and other academic qualification.

The analysis of the relation between employees' highest education and their ISEI-value (International Socio-Economic Index of occupational status [22; 23]) for their first as well as for their current job shows how educational attainment is related to individual social status (see figure 1). 
Table 2: Returns of investment in education in Germany

\section{Compared educational groups Income (comparing ... to ...) ) difference}

\begin{tabular}{lr}
\hline $\begin{array}{l}\text { Academic qualification to further } \\
\text { education }\end{array}$ & $2.78 \%$ \\
BA to further education & $-0.85 \%$ \\
\hline & \\
\hline Further education to IVET & $7.14 \%$ \\
BA to IVET & $4.8 \%$ \\
Academic qualification to IVET & $8.24 \%$
\end{tabular}

Source: Employment Survey 2012, own calculations

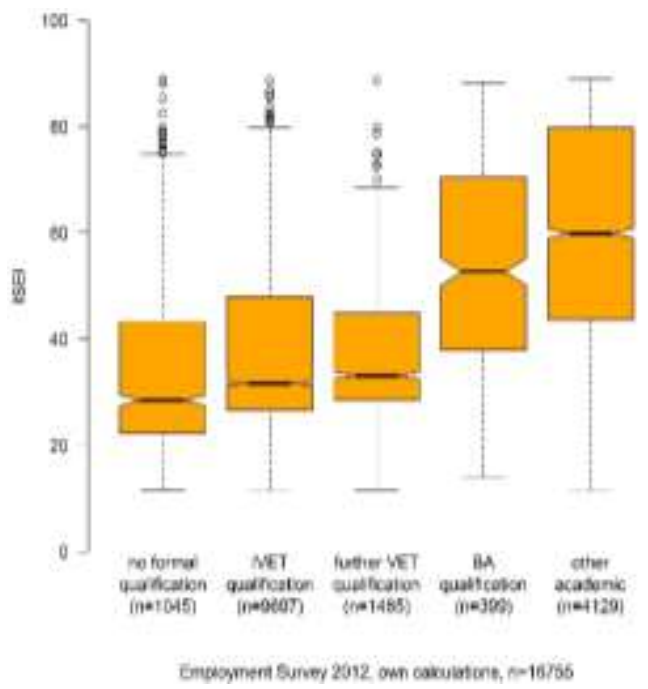

Figure 3. Highest qualification and ISEI of first job

Regarding the first job the results show that the differences between employees with no qualification in comparison to those holding an initial or a further vocational qualification are rather small - albeit the notches in the boxes indicate probably significant differences in medians. However, employees with an academic qualification reach considerably higher ISEI-values in their first job, with other than BAgraduates fairing significantly better than those who entered the labor market with a BA degree. Hereby the range of achieved ISEI-values among academically qualified employees is remarkable and raises questions regarding further deepened analysis for different fields of study and different degrees (bachelor, master, $\mathrm{PhD}$ ).

Looking at employees' current jobs the results change gradually (figure 4). Other than in the case of the first job here initial vocational qualifications and further vocational qualifications show an even more positive effect on individuals' ISEI-values. Although there are considerable overlaps between the boxes of individuals without a qualification and those with an (initial or further) vocational qualification the effect of an academic qualification on employees' ISEIvalues with the same distinction between BA- and other academic qualifications. Also the ranges for all academically qualified individuals in comparison to the results for the first job shrink.

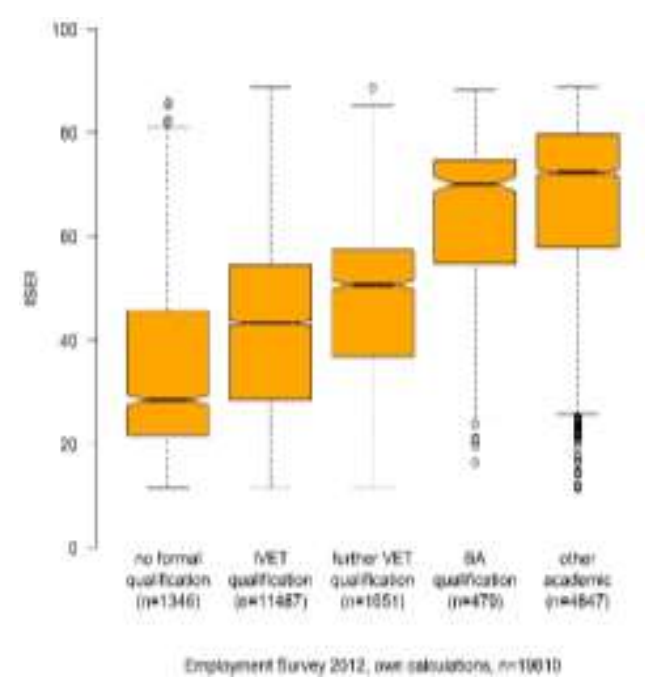

Figure 4. Highest qualification and ISEI of current job

The relation of social background and individuals' educational attainment is shown in figure 5. The data allow the calculation of the ISEI-value for the job of the respondents' father at the age of 15 , which is used as a measure for the social background.

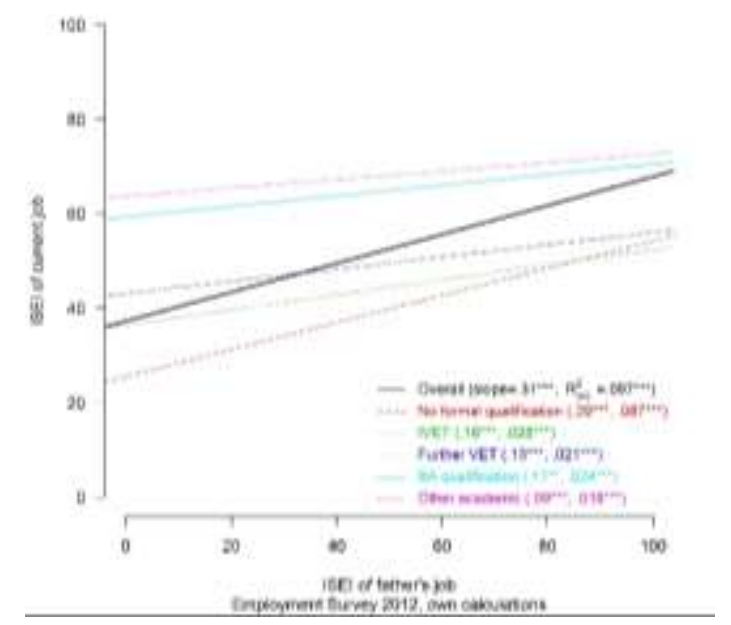

Figure 5. ISEI of father's and respondent's current job for different qualification levels

The results show that lower social background (i.e. lower ISEI-values for father's occupation) are characteristic for individuals who hold no qualification, an initial or a further vocational 
qualification. Again the group of academically qualified employees reaches higher ISEI scores. Social status is related to educational attainment of individuals and also, even if not very strong, related to social background. The influence of lower ISEIvalues of the father's job is most remarkable for unqualified individuals and least strong for academics, meaning that a higher education will always yield a higher status, but within a qualification level one's social background positively influences one's status. Theoretically someone with no formal qualification but a high status social background could even reach a higher status than someone with an IVET-qualification - but in reality the ISEI values only range up to under 90 points, which is where the two lines meet.

Visual inspection can give first insights, but we will deepen these in two simple OLS regression models. Besides social background as father's ISEI and educational attainment we also included several control variables which might influence occupational status. Table 3 shows the results for the first occupation.

You can see that indeed social background has a significant, but small influence $(0.07 *$ respective ISEI score for father's occupation, e.g. $0.07 * 50 \approx 3.5$ ) with a theoretical increase of about $6.3(=0.07 * 90)$ points for the first occupation's ISEI value. This is less than the influence of other academic qualifications as well as high general education. Again, a BA-degree yields less advantage than other academic degrees, but more than vocational qualification degrees.

Table 3. Linear regression on ISEI of first occupation

\begin{tabular}{|c|c|c|c|}
\hline ISEI of first occupation & $\widehat{\boldsymbol{\beta}}$ & std.err. & $\mathbf{p}$ \\
\hline Intercept & -30.05 & 3.39 & 0.000 \\
\hline \multicolumn{4}{|c|}{ Occupational qualification (ref.: IVET) } \\
\hline No qualification & -3.23 & 0.58 & 0.000 \\
\hline Further education & -0.70 & 0.46 & 0.125 \\
\hline BA & 6.20 & 0.91 & 0.000 \\
\hline Other academic & 12.75 & 0.41 & 0.000 \\
\hline ISEI father & 0.07 & 0.01 & 0.000 \\
\hline Female & 5.39 & 0.26 & 0.000 \\
\hline \multicolumn{4}{|c|}{ General education (ref.: no education) } \\
\hline Low & 2.65 & 2.53 & 0.295 \\
\hline Medium & 6.97 & 2.53 & 0.006 \\
\hline High & 10.50 & 2.55 & 0.000 \\
\hline Age at first job & 4.01 & 0.19 & 0.000 \\
\hline$(\text { Age at first job) })^{2}$ & -0.06 & 0.00 & 0.000 \\
\hline
\end{tabular}

Adj. R-squared: $0.4276(p \approx 0.000)$

Source: Employment Survey 2012, own calculations
In their first job people might start with lower status occupations and positions, especially when they prepare to move up a vocational career path. In these cases one will start with an initial vocational qualification and then achieve further vocational qualification degrees. Table 4 looks at results for respondents' current occupations, where these career steps could already have been taken.

Table 4. Linear regression on ISEI of current occupation

\section{ISEI of current occupation $\widehat{\boldsymbol{\beta}} \quad$ std.err. $\quad p$}

\begin{tabular}{|c|c|c|c|}
\hline Intercept & 26.23 & 2.47 & 0.000 \\
\hline \multicolumn{4}{|c|}{ Occupational qualification (ref.: IVET) } \\
\hline No qualification & -1.51 & 0.57 & 0.000 \\
\hline Further education & 1.79 & 0.46 & 0.011 \\
\hline BA & 3.14 & 0.90 & 0.000 \\
\hline Other academic & 2.85 & 0.47 & 0.000 \\
\hline ISEI father & 0.05 & 0.01 & 0.000 \\
\hline Female & 0.46 & 0.25 & 0.063 \\
\hline \multicolumn{4}{|c|}{ Required qualification (ref.: IVET) } \\
\hline No qualification & -7.94 & 0.37 & 0.000 \\
\hline Further education & 5.82 & 0.50 & 0.000 \\
\hline Academic & 14.22 & 0.43 & 0.000 \\
\hline \multicolumn{4}{|c|}{ General education (ref.: no education) } \\
\hline Low & 0.70 & 2.45 & 0.776 \\
\hline Medium & 5.17 & 2.45 & 0.035 \\
\hline High & 9.78 & 2.46 & 0.000 \\
\hline \multicolumn{4}{|c|}{ Age group (ref.: 35 to under 50 ) } \\
\hline Younger than 35 & -1.38 & 0.38 & 0.000 \\
\hline Older than 50 & 0.13 & 0.26 & 0.629 \\
\hline ISEI first occupation & 0.27 & 0.01 & 0.000 \\
\hline
\end{tabular}

Adj. R-squared: $0.5494(p \approx 0.000)$

\section{Source: Employment Survey 2012, own} calculations

Compared to the first occupation here we note a distinctive positive reward for further vocational education (1.79). Again, social background is only one factor among others. Interestingly, for the current job one's vocational qualification becomes less important than with the first job. Now age (also as a proxy for tenure) and the required qualification to be able to work in one's job notably influence occupational status. The first occupation's ISEIvalue has a considerable effect as well and might effectively even be higher than the influence of a required academic qualification, depending on the ISEI-value of the first occupation. 


\section{Conclusion}

In a nutshell the above analyses document a positive influence of higher educational qualifications on monetary as well as social attainment. While further vocational education and academic qualifications both lead to higher incomes compared to VET qualifications (except for bachelor's degrees) the results differ when looking at the employees' social status measured by the ISEI.

Regarding social status academic qualifications generally go along with higher social status, but (initial as well as further) vocational qualifications also develop a positive effect on social status over time compared to the group of unqualified persons. Still this effect is linear throughout and the model indicates that vocational qualification might always lead to lower status occupations compared to academic qualification. Interestingly social background also seems to favor especially academically qualified employees and to disadvantage especially unqualified individuals.

These results furthermore seem to support the assumption found in German literature on educational decisions, which suggests that expectations like higher prestige and a higher wage as well as expected access to a broader set of followup programs are central criteria for choosing an academic qualification instead of a vocational qualification [24; 25]. Although so far in Germany the highest share of a cohort enters the vocational training system and gains a respective qualification instead of an academic qualification, there is a continuing trend towards academisation as graduates from general schools increasingly tend to choose an academic instead of a vocational qualification [26]. Those educational decisions seem to be rational against the background of the results presented here. Still it has to be considered that especially further vocational qualifications lead to comparable monetary attainment and that (initial and further) vocational education also develop positive effects on social status over time.

Two aspects are worth considering here as well. The actual life-time incomes might bring about different results especially for the group of bachelor graduates. Since even no, more than a decade after their introduction, only very few graduates with this degree actually enter the labour market it is hard to assess correct numbers for their respective overall and also life-time earnings. Additionally we see that the qualification careers of these qraduates are not yet clear, as presently most of them go on to do master programmes. Thus, the competition between bachelor graduates and persons with further training qualifications might not become a broad phenomenon. It still remains to be seen, how firms actually react to this new qualification.
The results also raise the question which of the above mentioned criteria influence individuals' educational decisions and which role equal access plays in this context. This question will be an important element of the follow-up survey to the German BIBB/BAuA Employment Survey 2017/18.

\section{References}

[1] Hall, A./Siefer, A./Tiemann, M.: BIBB/BAuA Employment Survey of the Working Population on Qualification and Working Conditions in Germany 2012. Suf_4.0; Research Data Center at BIBB (ed.); GESIS Cologne (data access); Bonn: Federal Institute for vocational Education and Training. Doi: 10.7803/501.12.1.1.40, 2015.

[2] Rohrbach-Schmidt, D./Hall, A.: BIBB/BAuA Employment Survey 2012, BIBB FDZ Data and Methodological Reports Nr. 1/2013, Federal Institute for Vocational Education and Training, Research Data Center, Bonn, 2013.

[3] Kopatz, S./Pilz, M.: The Academic Takes it All? A Comparison of Returns to Investment in Education between Graduates and Apprentices in Canada. In: International Journal for Research in Vocational Education and Training, 2, 4, 2015, pp. 308-325

[4] Jacob, M./Klein, M./Iannelli, C.: The Impact of Social Origin on Graduates' Early Occupational Destinations An Anglo-German Comparison. In: European Sociological Review 31, 4, 2015, pp. 460-476

[5] Breen, R.: Social Mobility in Europe. Oxford: Oxford University Press, 2004.

[6] OECD: Education at a glance: OECD Indicators. Paris 2015.

[7] Baethge, M./Baethge-Kinsky, V.: Ökonomie, Technik, Organisation: Zur Entwicklung von Qualifikationsstruktur und Qualifikationsprofilen von Fachkräften. In: Arnold, R./Lipsmeier, A. (Hrsg.): Handbuch der Berufsbildung. 2. überarbeitete und aktualisierte Aufl. Wiesbaden: Verlag für Sozialwissenschaften, 2006.

[8] Baethge, M./Solga, H./Wieck, M.: Berufsbildung im Umbruch. Signale eines überfälligen Aufbruchs. URL: http://library.fes.de/pdf-

files/stabsabteilung/04258/studie.pdf (Stand: 03.06.2015), Berlin 2007.

[9] Pfeiffer, S.: Wissenschaftliches Wissen und Erfahrungswissen, ihre Bedeutung in innovativen Unternehmen und was das mit (beruflicher) Bildung zu tun hat, in: Kuda, E./Kaßebaum, B./Spöttl, G./Strauß, J. (Hrsg.): Akademisierung der Arbeit: Hat berufliche Bildung noch eine Zukunft? Hamburg, 2012, pp. 203 - 219

[10] Tiemann, M.: Wissensintensität von Berufen und ihre Entlohnung. Klassifikation und empirische Ergebnisse. In: Dietzen, A., Powell, J. J. W., Bahl, A., Lassnigg, L.: Soziale Inwertsetzung von Wissen, Erfahrung und 
Kompetenz in der Berufsbildung, BeltzJuventa, 2015, pp. 281-299

[11] Autor, D. H./Levy, F./Murnane, R. J.: The skill content of recent technological change: an empirical exploration. In: Quarterly Journal of Economics 118, 4, 2003, pp. 1279-1333

[12] Autor, D. H./Handel, M. J.: Putting Tasks to the Test: Human Capital, Job Tasks and Wages. NBER Working Paper No. w15116, 2009.

[13] Spitz-Oener, A.: Technical Change, Job Tasks, and Rising Educational Demands: Looking outside the Wage Structure. In: Journal of Labour Economics 24, 2, 2006.

[14] Goos, M./Manning, A.: Lousy and Lovely Jobs: the Rising Polarization of Work in Britain. In: Centre for Economic Performance Working Paper, 2003.

[15] Lörz, M./Quast, H./Roloff, J.: Konsequenzen der Bologna-Reform: Warum bestehen auch am Übergang vom Bachelor- ins Masterstudium soziale Ungleichheiten?. In: Zeitschrift für Soziologie 44, 2, 2015, pp. 137-155

[16] Protsch, P.: Segmentierte Ausbildungsmärkte. Berufliche Chancen von Hauptschülerinnen und Hauptschülern im Wandel. Budrich UniPress, Opladen 2014.

[17] Doeringer, P. B./Piore, M. J.: Internal Labor Markets and Manpower Analysis. Lexington, Mass. 1971.

[18] Piore, M. J.: Dualism in the Labor Market: A Response to Uncertainty and Flux. The Case of France. In: Revue économique 29, 1, 1987, pp. 26-48

[19] Psacharopoulos, G./Ng, Y. C.: Earnings and Education in Latin America. In: Education Economics, 2, 2, 1994, pp. 187-207

[20] Annen, S./Tiemann, M.: Educational pathways and decisions - Comparing the returns to investment in Germany and Canada. In: International Journal of Technology and Inclusive Education (IJTIE), 6, 1, June 2017, pp. 989-995

[21] Annen, S./Tiemann, M.: Typische Bildungsverläufe und Karrierewege in ausgewählten kaufmännischen Berufsbereichen - Konkurrenz und Komplementarität zwischen beruflich und akademisch Qualifizierten: Forschungsprojekt. Bonn 2016.

[22] Ganzeboom, H. B. G.: A new international socioeconomic index (ISEI) of occupational status for the international standard classification of occupations 2008 (ISCO-08) constructed with data from the ISSP 20022007; With an analyses of quality of occupational measurement in ISSP. Paper presented at the Annual Confernce of International Social Survey Programme, Lisbon, May 2010

[23] Ganzeboom, H. B. G./Treiman, D. J.: Internationally Comparable Measures of Occupational Status for the 1988 International Standard Classification of Occupations. In: Social Science Research 25, 1996, pp. 201-239
[24] Dobischat, R./ Fischell, M./Rosendahl, A.: Auswirkungen der Studienreform durch die Einführung des Bachelorabschlusses auf das Berufsbildungssystem Eine Problemskizze, Düsseldorf 2008.

[25] Severing, E./Teichler, U.: Akademisierung der Berufswelt? Verberuflichung der Hochschulen? In: Severing, E./Teichler, U.: Akademisierung der Berufswelt? Bielefeld, 2013, pp. 7-18

[26] Bundesinstitut für Berufsbildung (BIBB): Datenreport zum Berufsbildungsbericht 2015 - Informationen und Analysen zur Entwicklung der beruflichen Bildung, Bonn 2015 .

[27] Weiß, Reinhold: Bachelor Professional - ein Beitrag zur Aufwertung der beruflichen Bildung? In: BWP 4/2007, S. 47-50

[28] Baethge, M.; Kerst, C.; Leszczensky, M.; Wieck, M.: Zur neuen Konstellation zwischen Hochschulbildung und Berufsausbildung. HIS: Forum Hochschule 3 / 2014, Hannover 2014, URL: http://www.dzhw.eu/pdf/pub_fh/fh201403.pdf (03.06.2015)

[29] Konegen-Grenier, C.; Placke, B.; SchröderKralemann, A.: Karrierewege für Bachelorabsolventen Ergebnisbericht zur Unternehmensbefragung 2014. Stifterverband für die Deutsche Wissenschaft (Hrsg.), Analysen, Essen 2015 URL: http://www.stifterverband.de/pdf/ bachelorabsolventen.pdf (29.05.2015)

[30] Briedis, K.; Heine, C.; Konegen-Grenier, C.; Schröder, A.: Mit dem Bachelor in den Beruf. Arbeitsmarktbefähigung und -akzeptanz von Bachelorstudierenden und -absolventen. Essen 2011 URL: http://www.stifterverband.org/publikationen_und_podcasts /positionen_dokumentationen/mit_dem_bachelor_in_den_ beruf/mit_dem_bachelor_in_den_beruf.pdf (Stand: 29.05.2015)

[31] Deutscher Industrie- und Handelskammertag e. V. (DIHK): Erwartungen der Wirtschaft an Hochschulabsolventen. [32] Annen, S./Tiemann, M.: Employability of academically and vocationally qualified employees - theoretical reflections and empirical evidence from the commerce sector in Germany. In: International Journal of Learning and Teaching, Volume 3, Number 3, 2016, S. 241-246 